\title{
KEYNOTE \\ INVOLVEMENT OF GENETICS IN KNOWLEDGE, STOCK MANAGEMENT AND CONSERVATION OF AUSTROPOTAMOBIUS PALLIPES IN EUROPE
}

\author{
C. SOUTY-GROSSET, F. GRANDJEAN, N. GOUIN
}

Laboratoire de Génétique et Biologie des Populations de Crustacés, UMR CNRS 6556, Université de Poitiers, 40, avenue du Recteur Pineau, F-86022 Poitiers Cedex, France. E-Mail: catherine.souty@univ-poitiers.fr

\begin{abstract}
In the past, conservation programmes for a given species consisted in restoring the habitat and in translocating individuals without knowledge of their taxonomic status. Even if managers wanted to be informed, the "traditional taxonomy", based on morphological characters, was discouraging because it could indicate several types of classification. This is the case for Austropotamobius pallipes, considered as a species complex.

Today, conservation genetics aims to maintain, on one hand, the genetic specificity of populations (genetic integrity principle) and, on the other hand, the genetic diversity within and between populations (biodiversity principle), these basic principles being considered both at the level of protection measures and management measures. As an endangered species, $A$. pallipes is subjected to a loss of genetic diversity, a result of deterioration of water quality responsible for habitat fragmentation, with populations being confined to headwaters of the catchments. Consequently a certain degree of genetic variability must be maintained within the species because it governs the adaptation potential: the populations must be capable of responding to new environmental conditions.
\end{abstract}

In $A$. pallipes, recent studies from several countries attempt to first describe the distribution of the present natural populations and secondly, by studying mitochondrial DNA, to clarify the taxonomy (number and identification of the present species and subspecies by phylogenetic inferences) and to assess the biogeographical history. These two preliminary steps are fundamental before defining conservation units and working at the catchment level, using highly polymorphic nuclear markers. The new approach has provided a good framework for research, with more frequent dialogues between geneticists and managers.

Key-words: Austropotamobius pallipes, taxonomic clarifications, population genetics, conservation genetics. 


\section{APPORTS DE LA GÉNÉTIQUE À LA CONNAISSANCE, LA PROTECTION ET LA CONSERVATION D'AUSTROPOTAMOBIUS PALLIPES EN EUROPE}

\section{RÉSUMÉ}

Dans le passé, les programmes de conservation d'une espèce donnée consistaient à restaurer l'habitat et à pratiquer des translocations d'individus sans une connaissance préalable de leur statut taxonomique. Même si les gestionnaires voulaient être informés, la " taxonomie traditionnelle », basée sur des critères morphologiques, les décourageait car elle recouvrait plusieurs types de classification. C'est le cas d'Austropotamobius pallipes, considérée alors comme un complexe d'espèces.

Actuellement la génétique de la conservation a pour but de maintenir, d'un coté, la spécificité génétique des populations (principe de l'intégrité génétique) et, d'un autre côté, la diversité génétique intra- et inter-populationnelle (principe de biodiversité), ces deux principes de base étant considérés comme primordiaux en termes de mesures de protection et de gestion. En tant qu'espèce en danger, $A$. pallipes est sujette à une perte de diversité génétique, conséquence de la détérioration de la qualité de l'eau ayant pour conséquence la fragmentation de l'habitat, les populations étant confinées en tête de bassin. Or un certain degré de variabilité génétique doit être maintenu au sein de l'espèce car cette variabilité gouverne le potentiel adaptatif : les populations doivent être capables de répondre à de nouvelles conditions environnementales.

Chez A. pallipes, des études récentes menées dans différents pays d'Europe tentent d'abord de décrire la distribution actuelle des populations naturelles et ensuite, par l'étude du marqueur mitochondrial, de clarifier la taxonomie (nombre et identification des espèces et sous espèces actuelles par études phylogénétiques) et de décrire leur histoire biogéographique. Ces deux étapes préliminaires sont incontournables avant de vouloir définir des unités de conservation et de travailler à l'échelle du bassin hydrographique, par utilisation de marqueurs nucléaires hautement polymorphes. Ces nouvelles approches conduisent à une bonne conduite de recherche qui, de plus, inclut maintenant des dialogues plus fréquents entre généticiens et gestionnaires.

Mots-clés: Austropotamobius pallipes, révisions taxonomiques, génétique des populations, génétique de la conservation.

\section{INTRODUCTION}

In Europe, crayfish are under several pressures such as (1) pollution from domestic, agricultural, or industrial wastes being probably the single most significant factor in causing major declines in the populations (2) habitat loss (3) overfishing /overexploitation and (4) introduction of alien species disseminating diseases such as crayfish plague in Europe.

For example, white-clawed crayfish (Austropamobius pallipes) populations have declined by between $25-49 \%$ over the last 25 years in Europe. A. pallipes is included in Appendix III of the Bern Convention (Convention on the conservation of European wildlife and natural habitats - JO August 28, 1990 and August 20,1996) as a protected species. The constant decline of natural populations of $A$. pallipes over the past 30 years encouraged the IUCN International Union for the Conservation of Nature and Natural Resources to include the species in the Red Data List of endangered species (GROOMBRIDGE, 1993). In response to the Convention on Biological Diversity signed at the Earth Summit in Rio de Janeiro in 1992, the species was also included in Annex II of the Habitat Directive 92/43/CEE of the European Community which related to the conservation of natural habitats of wild fauna and flora. This annex is devoted to animal and plant species of European interest as a result of which several Special Areas of Conservation (SAC) have been designated. This 
Directive (JOCE July 22, 1992) advocates conservation rules and has included in Annex V the native crayfish species under the title "animal and plant species of European interest whose capture and trade are to be submitted to management measures". Consequently, heritage management is strongly recommended through integration of the protection of endangered species and their habitats.

In France, since 1995, A. pallipes populations are still found in 72 to 73 of the 95 existing departments but with a loss of entire populations in 14 departments and a significant lowering of density in 26 departments in 2001 (CHANGEUX, 2002).

Applied to such an endangered species, conservation biology is a multidisciplinary science involving three approaches: species-population, habitat-area and ecosystem landscape. The study of species and populations implies knowledge in systematics, ecology, ethology and particularly population genetics (Figure 1): when the natural populations have lower sizes, loss of genetic diversity reduces their ability to adapt to changes in the environment, with inbreeding depression (reduction of fitness for individuals produced via mating of close relatives), an inevitable consequence for many species. Isolated populations may have trouble maintaining the genetic integrity and variability needed for their continued evolutionary viability and prospects for long-term survival, if they cannot migrate or are isolated from other populations. Apart from the maintenance of genetic variability within populations, the preservation of the integrity of locally well-adapted gene pools is one of the major issues in population genetics. Sound knowledge of systematic relationships of a given taxon, especially with problems such as geographically separated populations or closely related species, is thus essential for restocking operations, for promoting gene flow by translocation of animals and for

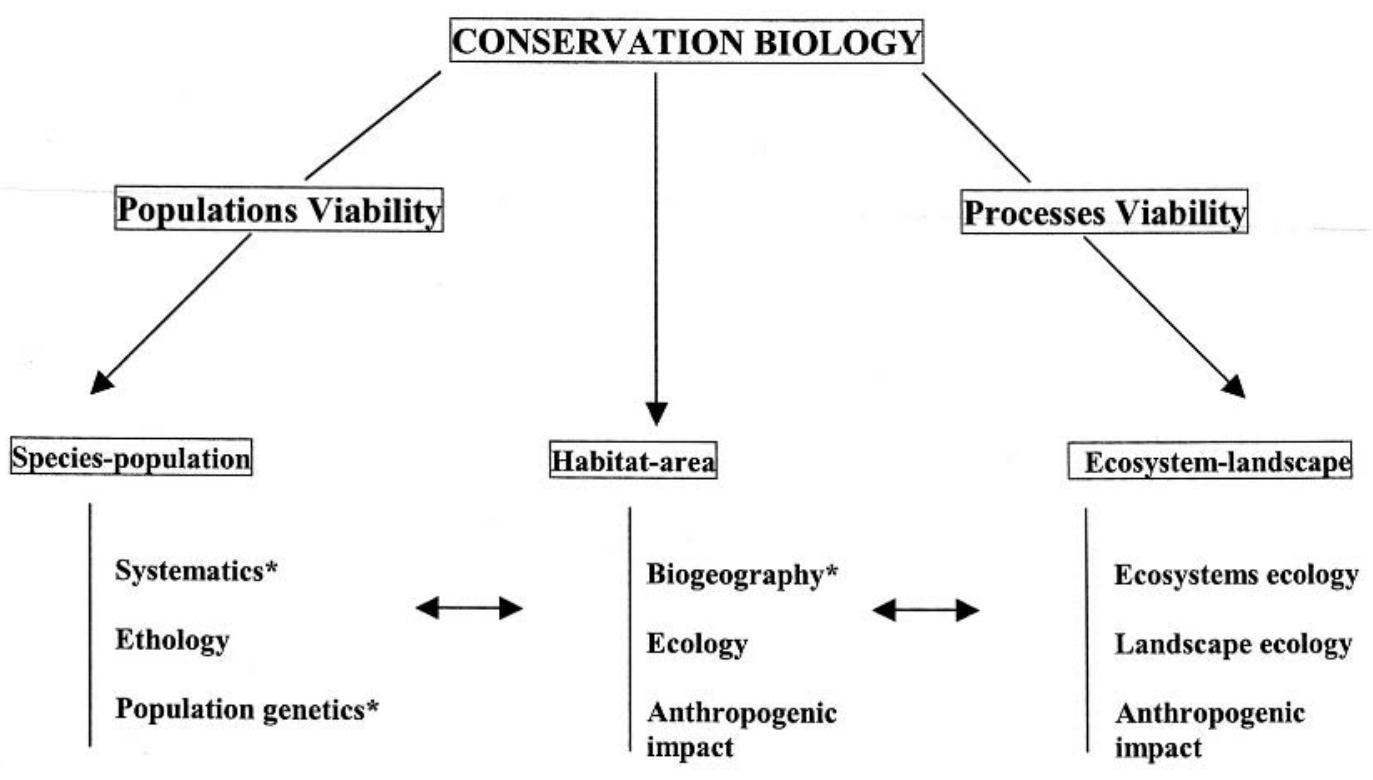

Figure 1

Implementation of the three main topics of conservation genetics. $\left(^{*}\right)$ in the area of conservation biology.

Figure 1

Les trois principales approches en génétique de la conservation (*) dans le domaine de la biologie de la conservation. 
assessing priorities in the preservation of particular populations. Consequently, priorities are to provide: (1) a description of the quantity and distribution of genetic variation, (2) an estimation of historic levels of isolation and gene flow, (3) an identification of unique gene pools for special protection, (4) information on choosing brood stocks, and (5) monitoring of reared populations. Only through informed scientific management can the probabilities for conservation of rare species be maximized.

Information about the genetic diversity of a species assists scientists and managers in forming strategies to preserve and protect the diversity of this species. If genetic diversity becomes low at many genes of a species, that species becomes increasingly at risk. If new pressures (such as environmental disasters) occur, a population with high genetic diversity has a greater chance of having at least some individuals with a genetic make-up that allows them to survive. If genetic diversity is very low, none of the individuals in a population may have the characteristics needed to cope with the new environmental conditions. In any species, it is first necessary to know what are the forms or taxa described by morphological features. After that, the relationships can be evaluated between taxa by examining genetic characteristics of the organism by protein or DNA markers. Consequently, it is necessary to know how much diversity exists in separate populations of the same species and the rate at which the exchange of genetic information (gene flow) is occurring between populations.

Finally a management programme will be constructed between scientists and managers working together and must result not only in a restoration of the habitat as it was in the past but also from a reliable genetic study, permitting management of the population itself in case of repopulation or of reinforcement by selecting those individuals capable of providing good genetic variability.

\section{WHAT IS CONSERVATION GENETICS?}

The science of conservation biology deals with individuals and populations that have been affected by not only habitat loss but also exploitation and/or environmental changes. This information is used to make informed decisions to ensure the survival of that species in the future; as genetics is the study of inheritance and the investigation of the genes responsible for inherited traits; both conservation biology and genetics result in conservation genetics. This type of research is relatively recent (1990s) since allozymes and DNA have allowed new perspectives through the study of the genetic structure of a species, a population and even an individual.

Concerning the management of crayfish populations themselves, as mentioned above, biologists require first a knowledge of species distribution and life histories. There are several major conservation genetics issues (Figure 2) including fragmentation of populations and reduction in gene flow because of no exchanges between the populations and genetic drift (process driven by random sampling of gametes each generation that can produce changes in alleles frequencies over time; it is more pronounced in small populations). After understanding species biology, the next step is resolving taxonomic uncertainties, because it is necessary to know first what are the forms or taxa described by morphological features? One of the fundamental goals is to group those individuals having morphological and genetic similarity (i.e. to link accurate morphological characters with genetic results). Are there several subspecies within a given geographical area? A second question is what are the relationships between taxa? This can be resolved by examining genetic characteristics of the organism by DNA. After that it is possible to investigate evolutionary genetics, if there is introgression (introduction of genetic material from another species or subspecies into a population) and finally the population structure depending on the degree of fragmentation of the habitat 


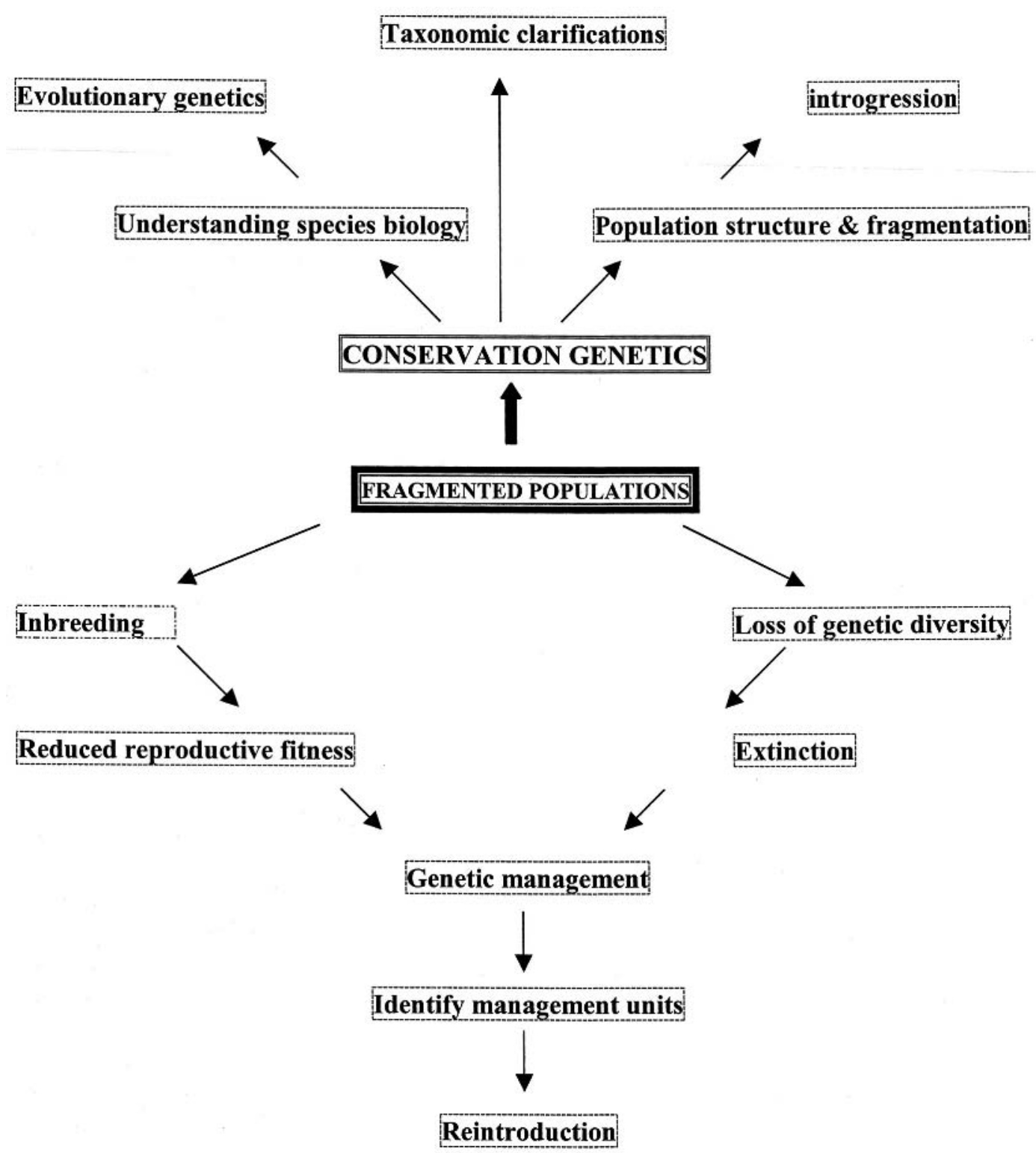

Figure 2

Relevance of conservation genetics: as soon as the populations become reduced in size and subjected to a loss of genetic diversity, a management plan can be undertaken owing to conservation genetics with the two main topics: taxonomic clarifications and population structure resulting from the impact of the fragmentation. The main objective of genetic management is to minimize inbreeding and loss of genetic diversity.

Figure 2

Importance de la génétique de la conservation: dès que les populations réduisent de taille et sont soumises à une perte de la diversité génétique, un plan de gestion peut être entrepris grâce à la génétique de la conservation dont les deux approches fondamentales sont les clarifications d'ordre taxonomique et la structure des populations résultant de leur fragmentation. L'objectif majeur de la gestion génétique est de réduire l'inbreeding et la perte de la diversité génétique. 


\section{CONSERVATION UNITS}

MORITZ (1994) proposed the identification of conservation units based on genetic criteria arising from the study of different molecular markers. He named these Evolutionarily Significant Units (ESUs): they correspond to partially genetically differentiated populations that are considered to require management as separate units. ESUs have been defined as reciprocally monophyletic for mitochondrial DNA and also significantly different in frequencies at nuclear loci. MORITZ also defined Management Units (MUs) as populations that are functionally independent and have low current levels of gene flow among them, attested by statistically significant differences of allelic frequencies for nuclear markers.

At the core of the application of ESUs are philosophical differences concerning the answers to questions such as: What is a species? How can species be identified? How can this systematic information be used to inform and implement conservation measures for species, locally threatened populations of species and habitats?

\section{Problems of taxonomy and knowledge of $A$. pallipes distribution}

Historically, species and subspecies have been defined by morphological characters. Yet this method can only tell a part of the story. Often, a species evolutionary history includes the separation of populations. In prehistory many species were split apart by ice, desert or ocean over periods that allowed for compensatory adaptation, that is, they became separated for long enough to become different species or subspecies. Biologists need to resolve the first problem of taxonomy which can be complex: A sound knowledge of systematic relationships in a given taxon, especially within the problematic range from geographically separated populations to closely related species, is essential for restocking operations, for promoting gene flow by translocation of animals and for assessing priorities in the preservation of particular populations.

European crayfish have been subjected of a number of taxomomic revisions that have, at the simplest level, produced a system with 1 genus and 5 species (ALBRECHT, 1982) and at the most complex, 5 genera and 19 species (STAROBOGATOV, 1995). This fact shows that classical taxonomical methods are sometimes not powerful enough (FUREDER and MACHINO, 2002) to differentiate groups along phylogenetic lines and also to provide a precise delimitation of closely related species or intraspecific taxa. The classical taxonomy of $A$. pallipes is a good example of this aspect: the number of species, subspecies, or varieties may vary depending on the philosophical stance of authors and the taxonomy obtained by morphological characters studies revealed a complex species. For example, BOTT (1950) considered three subspecies: A. pallipes pallipes in France, England and Ireland; $A$. pallipes lusitanicus in Spain; A. pallipes italicus in Italy and Balkans. But KARAMAN (1962) defined two species with three subspecies within italicus and BRODSKY (1983) redefined two subspecies within pallipes and two within italicus. Thus the reliable taxonomy of the Austropotamobius complex is the first problem to be resolved before any conservation effort, as an inadequate taxonomy can have dramatic consequences in the management scheme. Resolution of species status was thus undertaken particularly in Austropotamobius pallipes spp (GRANDJEAN et al., 2000, 2002). GRANDJEAN et al (2002) have analysed mitochondrial 16S DNA sequences in different samples coming from Ireland, France and Corsica, Spain, Italy, Austria and Slovenia. The maximum likelihood analysis supports the separation of two major clades: the first: Austria, France, Italy, Slovenia, Spain; the second: France, Corsica, Ireland, U. K. Inside the first clade, 3 distinct subclades were defined: A1: Italy, Spain, France; A2: Austria; A3: Slovenia, France. Within group A, the three genetic groups are well assessed by high bootstrap values and we have redefined them as $A$. i. italicus, $A$. i. carsicus and $A$. i. carinthiacus. Results obtained for $A$. berndhauseri, a species described by LARGIADER et al., 2000) in Switzerland, were included. A. berndhauseri was, however, found not to be genetically distinct from $A$. $i$. carinthiacus distributed in Austria. Further, A. italicus is 
present in Spain; this is well in accordance with taxonomical results since $A$. lusitanicus was distinguished from $A$. italicus by a very limited taxonomic value according to the morphological characters. They were distinguished by the presence of hairs on the upper border of the endopod of the second male gonopod in A. lusitanicus. This result is important for advising field workers that this limited morphological observation is in fact not suitable for recognising another species.

In accordance with morphological data extracted from recent papers, a new classification based on the presence of three subspecies (A. italicus italicus, $A$. italicus carinthiacus and $A$. italicus carsicus) within $A$. italicus is now clearly proposed. Recent works of FRATINI et al. (personal communication) confirmed that, from a conservation point of view, Italy, with high haplotype diversity, might be considered as a "hot spot" for the genetic diversity of Austropotamobius. Consequently, re-introduction programmes must be operated with caution in this country, since the two Austropotamobius species (pallipes and italicus) as well the italicus subspecies are genetically and taxonomically separate units that require independent conservation plans.

This demonstrates the importance, from a conservation point of view, of taking into account genetically separate units. Moreover studies of variability within and between populations inside each defined unit can be undertaken only after this preliminary step of verifying the taxonomic uncertainties.

\section{BIOGEOGRAPHICAL DATA IN A. PALLIPES AT THE LEVEL OF ITS DISTRIBUTION AREA (WESTERN EUROPE)}

GRANDJEAN and SOUTY-GROSSET (2000) studied populations from Western Europe by mtDNA RFLP analysis in order to understand the role of its ancient and recent history and then to identify potential refugia, postglacial routes of recolonisation and the impact of human transplantation in the distribution of genetic variation. A cluster $A$ for $A$. pallipes was found, divided into 3 sub clusters: $A 1=$ Northwestern and northeastern France and British Isles; $A 2=$ Central and Southern France; $A 3=$ northwest Italy. $A$ cluster B concerned $A$. italicus comprising B1 = Italy and Spain; B2 = Slovenia and a French population; B3 = Austrian populations. According to HEWITT (1996), such results could be explained by the existence of refugial areas during the Pleistocene located to the south of major mountain ranges of Europe (Pyrenees, Alps, Transylvanians and Carpathians). In the $A$. pallipes complex, the four mtDNA lineages described agree with the presumption of at least four main refugia during the Pleistocene, which are located in the Balkans, Carpathians, Italy and France. This possibility is supported by the fact that these four Mediterranean regions contained unique haplotypes with a high genetic diversity within populations. The depth of nucleotide divergence indicates a more ancient separation than those resulting from the most recent glaciation periods, probably during the Upper Miocene. A. pallipes has recolonized England and Northern France from specimens originating from Western French refugia (R1). The Rhône, the Garonne, and a part of the Loire drainages have been recolonized by specimen from R2, while the Northern Italian populations originated from crayfish from $\mathrm{R} 3$. Three other main refugia $\mathrm{R} 4, \mathrm{R} 5$ and $\mathrm{R} 6$ have harboured $A$. italicus during the last glaciation periods from which it has recolonized ItalySouth of Switzerland, the Balkans and Austria-Switzerland respectively. Irish and Spanish populations are monomorphic with one haplotype shared with western French and Italian populations, respectively, suggesting a human origin of these two stocks. According to the definition of MORITZ (1994) - stating that Evolutionary Significant Units should be reciprocally monophyletic for mtDNA alleles and also differ significantly for the frequency of alleles at nuclear loci - it can only be suggested that reciprocal monophyly of mtDNA haplotypes was evident from Northern France, England, Wales and Southern France and two ESUs can be only postulated. 


\section{The case of France}

In France, it was evident that information was needed about the variability of nuclear genes in order to support the existence of these 2 ESUs. An exhaustive study on a significant number of populations markers was undertaken by GOUIN (2001) using microsatellites markers. These are relative newcomers to the world of DNA based methods. They are highly polymorphic and assess population substructure. Isolating microsatelllites from an organism is often difficult and time consuming. GOUIN et al. (2000) were the first to isolate microsatellites in $A$. pallipes. These markers were powerful in verifying the results obtained by mtDNA, for examining the role of hydrography and also for investigating the structure of population at the catchment and stream level.

GOUIN (2001) investigated the polymorphism of the microsatellites in 80 French populations in order to reconsider these biogeographical implications. Stocks were subdivided according to a south-western/north-eastern axis and this axis partitioned the basins of Loire and Rhône. A first result was the congruence of mtDNA, RAPDs (GOUIN et al., 2001) and microsatellites data and confirmed the existence of the subdivision of the French stock in France. The two entities are genetically well differentiated; there would exist thus an Atlantic strain and a Mediterranean one. The populations are highly structured within each group: this high level of genetic differentiation between the populations reflected an important isolation. The absence of gene flow between populations favoured the genetic structure under the effect of genetic drift. The Mediterranean populations have a higher genetic structure (compared with Atlantic ones), as was observed with mtDNA seeing that a higher allelic diversity in Mediterranean populations was described with microsatellites. Microsatellites revealed that a part of the genetic structure is expressed as a function of hydrography within the two groups: the role of hydrography is shown for the first time because this was not revealed by mtDNA RFLP (GOUIN, 2001).

However in the Garonne basin (sub basin Dordogne) mixed populations were found and it could be supposed that this area represents a zone of secondary contact between the Atlantic strain and the Mediterranean ones.

\section{The case of Ireland}

The white-clawed crayfish defined as $A$. pallipes is widespread throughout lowland Ireland. Ireland biogeography has long been of interest - a number of endemic species or subspecies have been identified, but there are also affinities with the fauna and flora of distant areas: Nordic, Celtic, continental and Lusitanian. One postulate is that Irish crayfish may be a relict of these stocks. But there is also a suspicion that crayfish are more likely to have been introduced from Great Britain. When Irish stocks were investigated with mtDNA RFLP, only one haplotype was found across all Irish populations which corresponds to the less frequent of the two haplotypes found in the French region Poitou-Charentes (GOUIN et al., 2003) Moreover the haplotype is quite different from the Spanish haplotypes. Consequently crayfish may have been introduced neither from England nor from Spain but from France. While LUCEY (1999) has unravelled the recent history of crayfish in Ireland and linked their documented presence in the sixteenth century to introduction from England, J. REYNOLDS (personal communication) notes that there were monastic orders from France as early as the twelfth century and perhaps introductions from Western France were made by them.

Moreover RAPD analysis showed a clinal reduction of genetic variability within Irish populations from south to north, associated with an increase of their genetic differentiation. A stepwise model of translocation from the south to the north of Ireland is proposed. The successive translocation events from the initial introduced (French) population in the south would have entailed a succession of founder effects responsible for this clinal reduction of genetic diversity. The colonization history may have happened step by step 
among geographically close locations, triggering a progressive genetic differentiation of populations along this axis under genetic drift effects. Therefore these results point out the strong impact of past-uncontrolled translocation events on genetic structuring in natural populations.

\section{The case of Spain}

In Spain, the results are also in accordance with the theoretical genetic consequence of translocation from a limited number of individuals: only one haplotype was found in 154 animals sampled from 14 Spanish populations and also shared with Italian ones (GRANDJEAN et al, 2001). This confirms that human introductions from Italy were at the origin of the Spanish populations, which are A. italicus. Moreover results are in accordance with a drastic bottleneck (severe reduction in population size) during the history of Spanish populations. This lack of genetic variation in the Spanish $A$. italicus stock could be the result of different and not exclusive events: not only human-mediated introduction but also selection (impact of the crayfish plague involving a selection and restriction of the genetic diversity) and recent historical events (acute population fragmentation in the last decades).

\section{USEFULNESS OF NUCLEAR MARKERS FOR STUDYING $A$. PALLIPES POPULATION STRUCTURE AT THE LEVEL OF CATCHMENT}

In France, at the scale of large catchments such as the Loire, Rhône and Garonne, a high level of genetic structure was observed as well as isolation by distance, leading to high degree of isolation of populations and high impact of genetic drift. After these large scale results, GOUIN (2001) focussed on the genetic structure within a small basin located in the Poitou Charentes region and where a lot of populations could easily be sampled: here a more limited degree of fragmentation was observed which could lead to a better understanding of how the populations function and to a better evaluation of the impact of the fragmentation on the genetic structure in $A$. pallipes.

In the same basin (Sèvre Niortaise), having an extent of less than $100 \mathrm{~km}$, 11 populations were sampled and a high degree of genetic structure was found relating to the important degree of fragmentation of the crayfish habitat. A profile of isolation by distance was also observed, reflecting a low dispersal of the species. These results were fundamental for asking the following questions: are there differences of effective population sizes? Are demographical fluctuations responsible for effective size of the populations? What are the impacts of translocation events? Consequently it is necessary to go to the field in order to correlate genetics with demographic data by estimating the size of the studied populations. The analysis of genetic and demographical parameters was very informative in $A$. pallipes, the genetic variability being strongly correlated with the size of the population. However, a recent bottleneck event was outlined in two populations. The effective sizes were very low because of the impact of demographical fluctuations on the decrease of genetic variation in isolated populations. Finally, among the eleven studied populations, only one population had a sufficient effective size for maintaining long-term genetic diversity.

GOUIN et al. (2002) focussed on the genetic structure of a population along a stream, since the knowledge of dispersal abilities in endangered species is a critical parameter in conservation biology. Six sites were sampled along the Magnerolles brook (Deux-Sèvres, France), covering the extent of the population (spread over 3000 meters). A high level of genetic polymorphism was found and no genetic differentiation between sites. These results suggest that this population is panmictic. In that case, at the level of the stream, the genetic homogeneity is probably due to extensive gene flow, both in 
the direction of stream flow and against it. Thus, in the absence of a barrier to gene flow, A. pallipes is able to disperse over long distances in a favourable environment. These genetic results revealed by microsatellites are in accordance with those recently obtained by radiotracking experiments on crayfish species (ARMITAGE, 2000). If translocation strategies are planed to manage populations, the relatively high ability of $A$. pallipes to disperse could permit the species to colonize all favourable habitats within a brook and probably on a larger scale if there are no barriers to migration.

\section{HOW TO MANAGE A. PALLIPES POPULATIONS IN FRANCE?}

Today, the protection of existing populations is proposed, particularly the more important population having a high genetic variability, is proposed. Translocations of some genitors from more polymorphic populations could be undertaken but this reinforcement must be made between populations from the same ESU and preferentially belonging to the same catchment. In the case of re-population of streams and headwaters, as there is no French farm for $A$. pallipes, this can be only done from natural populations having high polymorphism. Populations must be sampled inside the differentiated units. The zones of mixed populations must first be carefully investigated before any management of populations.

\section{CONCLUSIONS}

Management of $A$. pallipes populations requires both genetic information and suitable habitats. Restocking of habitats with native crayfish species is among the most important current management and conservation options (REYNOLDS, 1997; DEHUS et al., 1999). However, a successful restocking exercise requires a set of criteria related to habitats, stocking material and stocking procedure (REYNOLDS, 1998; REYNOLDS et al., 2000). The habitats to be restocked need to be still suitable for crayfish in terms of water quality, morphological structure and substrate type, and free of crayfish plague (HOLDICH and ROGERS, 2000; topic developed in the previous special issue: Poitiers, roundtable 4A, - vol. 367 - edited by SOUTY-GROSSET and GRANDJEAN, 2002). If introduction is planned it should also be assessed whether the crayfish may have any negative impact on other endangered species already inhabiting the target water body.

\section{WHAT DO WE MEAN BY A. PALLIPES?}

Genetic studies supply conservation biologists and field managers with new insights into the extent of diversity among the individuals in a population. Without using genetics, we may conserve the wrong subspecies and/or population. The species complex of $A$. pallipes is well recognised (LORTSCHER et al, 1997; MACHINO, 1997; GRANDJEAN et al., 2000 , 2002). According to GRANDJEAN et al. (2002) the identity of the taxon A. pallipes is clear across its northern and western range (particularly in France, Great Britain and Ireland). The situation is more complex with $A$. italicus which is shared between three subspecies in Spain, Italy, Austria and the Balkans: if there are subspecies and perhaps sibling species, conservation programmes should only take place after the preliminary insurance of a thorough knowledge of taxonomic entities, particularly in overlapping zones. "What do we mean by A. pallipes?" was the question discussed in a roundtable convened by Catherine Souty-Grosset (France) and Jose Carral (Spain) during the CRAYNET meeting in Kilkenny and which has given rise to this present issue. Discussions focussed on the difficulties in finding morphological evidence of species and subspecies: Pierre Noël proposed that a collection of the specimens studied in genetics could be constituted in order to determine "what are the reliable morphological characteristics". This work is fundamental 
because field workers must be capable of recognising the individuals from a description of suitable morphological characters, if they want to be sure of the determination of the subspecies. Further, P. Noël proposed that, through CRAYNET and with the help of the MNHN (Museum National Histoire Naturelle de Paris), it would be very interesting to look at very old specimens, particularly from populations which have now vanished. Moreover the statutory problem of recognising a new taxon formerly included in $A$. pallipes under European legislation must be resolved: Marcello laconelli (Italy) proposed the inclusion of A. italicus in the invertebrate Red Book data; Rosella Cianchi (Italy) stated that as there is a reproductive isolation of $A$. italicus, we must consider not one but two flagship species. Finally Pierre Noël (France) with the agreement of Paul Harding (UK) proposed $A$. pallipes as a new supra-species. It is thus urgent to revise the international and national legislation and ensure that the concerned southern countries transfer the information to the relevant authorities. This is one of the goals of the European network CRAYNET.

Phylogeography is very important because of the information conveyed about individual species and regional biotas for identifying Evolutionary Significant Units (ESUs) and Management Units (MUs).

The genetic relationships of the crayfish should consequently be taken into careful consideration. There are numerous studies reporting the genetic relationship of stocks at various geographic scales, both in the native species $A$. pallipes and Astacus astacus (SANTUCCl et al., 1997; SOUTY-GROSSET et al., 1997; SCHULZ and SYPKE, 1999) and the whole issue of crayfish genetics is still developing. It has been shown, for example, that the $A$. pallipes populations in the UK are closely related to populations from Western France (GRANDJEAN et al., 1997) and that Astacus astacus (L.) populations in lakes with a geographic distance as low as $20 \mathrm{~km}$ contain distinguishable populations (SCHULZ, 2000). While it is still difficult to draw any final conclusions from the studies on the genetic structure of some other crayfish species in relation to reintroduction measures, it is recommended to use a combination of different molecular methods (HAIG, 1998; SOUTY-GROSSET et al, 1999) and to carefully evaluate the results as described above for $A$. pallipes.

\section{ACKNOWLEDGEMENTS}

Special thanks are due to Julian Reynolds for suggesting this keynote communication as the team from the University of Poitiers performed the first genetic studies involving molecular markers such as mitochondrial DNA, RAPDs and microsatellites in Austropotamobius pallipes.

\section{REFERENCES}

ALBRECHT H., 1982. Das System der europäïschen Flusskrebse (Decapoda Astacidae): Vorschlag und Begrundung. Mitteilungen aus dem Hamburgischen Zoologischen Museum Institute, 79, 187-210.

ARMITAGE V., 2000. Observations of radio tracked crayfish (Austropotamobius pallipes) in a northern British river. Proceedings of the Crayfish Conference, Leeds, 63-69.

BOTT R., 1950. Die Flusskrebse Europas (Decapoda, Astacidae). Proceedings of the Senckenberg Naturalist Society, 483, 1-36.

BRODSKY S.Y., 1983. On the systematics of Palaearctic crayfishes (Crustacea, Decapoda). Freshwater Crayfish, 5, 464-470.

CHANGEUX T., 2002. Résultats commentés de l'enquête nationale écrevisses 2001. Service Technique Conseil Supérieur de la Pêche, $7 \mathrm{p}$. 
DEHUS, P., PHILIPSON, S., BOHL, E., OIDTMANN, B., KELLER, M., LECHLEITER S., 1999. German conservation strategies for native crayfish species with regard to alien species. In GHERARDI F., HOLDICH D.M. (ed.), Crayfish in Europe as alien species. How to make the best of a bad situation? 149-159, A.A. Balkema, Rotterdam and Brookfield.

FÜREDER L. and MACHINO Y., 2002. A revised determination key of freshwater crayfish in Europe. Bet. Nat. med. Verein Innsbruck, 89, 169-178.

GOUIN N., 2001. Apport des marqueurs nucléaires dans l'analyse de la structure génétique de l'écrevisse à pattes blanches Austropotamobius pallipes : implications pour sa conservation. Thèse de l'Université de Poitiers, $177 \mathrm{p}$.

GOUIN N., GRANDJEAN F., SOUTY-GROSSET C., 2000. Characterization of microsatellite loci in the endangered crayfish Austropotamobius pallipes (Astacidae) and their potential use in other decapods. Molecular Ecology, 9, 636-637.

GOUIN N., GRANDJEAN F., BOUCHON D., REYNOLDS J.D., SOUTY-GROSSET C., 2001. Genetic structure of the endangered freshwater crayfish Austropotamobius pallipes assessed using RAPD markers. Heredity, 87, 80-87.

GOUIN N., SOUTY-GROSSET C., ROPIQUET A., GRANDJEAN F., 2002. High dispersal ability of Austropotamobius pallipes revealed by microsatellites markers in a French brook. In SOUTY-GROSSET C., GRANDJEAN F. (eds). Knowledge-based management of European native crayfish. Crayfish special, vol. 4. Bull. Fr. Pêche Piscic., 367, 681-689.

GOUIN N., GRANDJEAN F., PAIN S., SOUTY-GROSSET C., REYNOLDS J.D., 2003. Origin and colonization history of the white-clawed crayfish, Austropotamobius pallipes, in Ireland. Heredity, 91, 70-77.

GRANDJEAN F. and SOUTY-GROSSET C., 2000. Mitochondrial DNA variation and population genetic structure of the white-clawed crayfish Austropotamobius pallipes pallipes. Conservation Genetics, 1, 309-319.

GRANDJEAN F., SOUTY-GROSSET C., RAIMOND R., HOLDICH D.M., 1997. Geographical variation of mitochondrial DNA between populations of the white-clawed crayfish Austropotamobius pallipes. Freshwater Biology, 37, 493-501.

GRANDJEAN F., HARRIS D.J., SOUTY-GROSSET C., CRANDALL K.A., 2000. Systematics of the European endangered crayfish species Austropotamobius pallipes (Decapoda: Astacidae). Journal Crustacean Biology, 20, 524-531.

GRANDJEAN F., GOUIN N., SOUTY-GROSSET C., DIEGUEZ-URIBEONDO J., 2001. Drastic bottleneck in the endangered crayfish species Austropotamobius pallipes in Spain and its implication for its colonization history. Heredity, 86, 431-438.

GRANDJEAN F., FRELON-RAIMOND F., SOUTY-GROSSET C., 2002. Compilation of molecular data for the phylogeny of the genus Austropotamobius: one species or several? In SOUTY-GROSSET C., GRANDJEAN F. (eds). Knowledge-based management of European native crayfish. Crayfish special, vol. 4. Bull. Fr. Pêche Piscic., 367, 663-670.

GROOMBRIDGE G. (ed.), 1993. IUCN red list of threatened animals. IUCN Gland, Switzerland and Cambridge, UK.

HAIG S.M., 1998. Molecular contributions to conservation. Ecology, 79 (2), 413-425.

HEWITT G.M., 1996. Some genetic consequences of ice ages and their role in divergence and speciation. Biological Journal of Linnean Society, 58, 247-276. 
HOLDICH D.M. and ROGERS W.D., 2000. Habitat requirements of the white clawed crayfish, Austropotamobius pallipes. In ROGERS and BRICKLAND, J. Crayfish Conference Leeds, 109-121.

KARAMAN M.S., 1962. Ein Beitrag zur Systematic der Astacidae. Crustaceana, 3, 173191.

LARGIADER C.R., HERGER F., LORTSCHER M., SCHOLL A., 2000. Assessment of natural and artificial propagation of the white-clawed crayfish (Austropotamobius pallipes species complex) in the Alpine region with nuclear and mitochondrial parkers. Molecular Ecology, 9, 25-37.

LORTSCHER M., STUCKI T.P., CLALUNA M., SCHOLL A., 1997. Phylogeographic structure of Austropotamobius pallipes populations in Switzerland. Bull. Fr. Pêche Piscic., 347, 649-661.

LUCEY J., 1999. A chronological account of the crayfish in Ireland. Bulletin of the Irish Biogeographical Society, 23, 143-161.

MACHINO Y., 1997. New white-clawed crayfish Austropotamobius pallipes (Lereboullet, 1858) occurences in Carinthia, Austria. Bull. Fr. Pêche Piscic., 347, 713-720.

MORITZ C., 1994. Defining evolutionary significant units for conservation. Trends in Ecology and Evolution, 9, 373-375.

REYNOLDS J.D, 1997. The present status of freshwater crayfish in Ireland. Bull. Fr. Pêche Piscic., 347, 693-700.

REYNOLDS J.D., 1998. Ireland's freshwaters. Dublin: Marine Institute.

REYNOLDS J.D., SOUTY-GROSSET C., GOUIN N., DEVANEY S., GRANDJEAN F., 2000. Experimental restocking of native cratfish in White lake, Co. Westmeath, Ireland.. In Crayfish Conference Leeds, ROGERS, D., BRICKLAND, J. eds, 123-130. Environment agency, Leeds.

SANTUCCI F., IACONELLI M., ANDREANI P., CIANCHI R., NASCETTI G., Bullini, L, 1997. Allozyme diversity of European freshwater crayfish of the genus Austropotamobius., Bull. Fr. Pêche Piscic., 347, 663-676.

SCHULZ R., 2000. Status of the noble crayfish Astacus astacus (L.) in Germany: monitoring protocol and the use of RAPD markers to assess the genetic structure of populations. Bull. Fr. Pêche Piscic., 356, 123-138.

SCHULZ R. and SYPKE J., 1999. Freshwater crayfish populations Astacus astacus (L.) in Northeast Brandenburg (Germany): analysis of genetic structure using RAPD - PCR. Freshwater Crayfish, 12, 387-395.

SOUTY-GROSSET C., GRANDJEAN F., RAIMOND R., FRELON M., DEBENEST C., BRAMARD M., 1997. Conservation genetics of the white-clawed crayfish Austropotamobius pallipes: The usefulness of the mitochondrial DNA marker. Bull. Fr. Pêche Piscic., 347, 677-692.

SOUTY-GROSSET C., GRANDJEAN F., GOUIN N., 1999. Molecular genetic contributions to conservation biology of the European native crayfish Austropotamobius pallipes. Freshwater Crayfish, 12, 371-386.

SOUTY-GROSSET C. and GRANDJEAN F. (eds.), 2002. Knowledge-based management of European native crayfish. Crayfish special, vol. 4. Bull. Fr. Pêche Piscic., 367, 402 p.

STAROBOGATOV Ya.I., 1995. Taxonomy and geographical distribution of crayfishes of Asia and East Europe (Crustacea Decapoda Astacoidei). Arthropoda Selecta, 4, 3-25. 